\title{
Women's leadership as a symbolic act of reproduction: A case Study in the Soloman Islands
}

\section{Susanne Maezama}

\begin{abstract}
Literature on women's leadership over the last three decades suggests that women's leadership perspectives have been predominantly influenced by either Euro-centric patriarchal views or those of women in economically developed countries. These are significantly different from an economically developing Pacific Island like the Solomon Islands, in particular, its Santa Isabel Island.

The literature, therefore, overlooks the impacts women's indigenous culture may have in order to understand their leadership beliefs and practices. Bourdieu (1977b) argues that people's practices are embodied within their cultures, forming habitus through their past and present experiences, both consciously and unconsciously. I argue that women leaders' leadership beliefs and practices cannot be fully understood without considering these social and cultural norms operating in their specific cultures. My thesis explores the impact of the Santa Isabel matrilineal culture on women's formed leadership beliefs and practices. The main research question therefore is:
\end{abstract}

How do women leaders' leadership beliefs and practices form in the Santa Isabel matrilineal culture? Sub questions arising from this are:

- In what ways does the Santa Isabel matrilineal culture influence women leaders' beliefs and practices?

- To what extent does the Santa Isabel matrilineal culture contribute to the formation of women leaders' cultural leadership beliefs and practices?

- How do women leaders practice leadership in the Santa Isabel matrilineal culture?

My research was undertaken using a case study methodology, linked with Bourdieu's (1977b) habitus as a lens for exploring women leaders' leadership practices in Santa Isabel in the Solomon Islands context through using interviews, informal observations and focus groups. The findings were generated through Bourdieu's (1977b) habitus theory for capturing an in-depth understanding of how women leaders' leadership beliefs and practices were formed. Key findings demonstrated that women leaders' leadership beliefs and practices were influenced by their matrilineal culture and early learning experiences in Santa Isabel. The study also revealed that these women leaders used leadership practices appropriate for their context. As a result, they formed leadership beliefs and practices that demonstrated a symbolic act of reproduction of their cultural habitus that reflected their existing leadership thinking.

The study has contributed to the research field by recognising the impact of cultural embodiment, the habitus and social reproduction of the Santa Isabel matrilineal culture on women's leadership beliefs

Wilf Malcolm Institute of Educational Research, Faculty of Education, University of Waikato, Hamilton, New Zealand ISSN: 2382-0373

Permanent Research Commons link to full thesis: http://hdl.handle.net/10289/10845

(pp. 111-112) 
and practices. It fills a critical gap in understanding women's leadership as a symbolic act of reproduction of their cultural beliefs and practices which has been overlooked in women's leadership literature. 